Reprod. Nutr. Dévelop., 1986, 26 (4), 1009-1015.

\title{
Autoradiography of ${ }^{3} \mathrm{H}$-uridine incorporation in the normal early blastocysts of cattle
}

\author{
J. PIVKO, V. KOPEČNÝ $\left({ }^{*}\right)(1), M$. TOMÁNEK, J. KAŇKA $\left({ }^{* *}\right)$, J.-E. FLÉ- \\ CHON $\left(^{* *}\right)$
}

Animal Production Research Institute, 949-92 Nitra, Czechoslovakia.

(*) Animal Production Research Institute, 251-61 Praha 10, Uhrinèves, Czechoslovakia.

(**) Institute of Physiology and Genetics of Animals, Czechoslovak Academy of Sciences, Libechov, Czechoslovakia.

(**) Institut national de la Recherche agronomique, Station de Physiologie animale, 78350 Jouy-en-Josas, France.

Summary. RNA synthesis in morphologicaly normal early bovine blastocysts collected 7 days after insemination was investigated using fine-structure autoradiography after ${ }^{3} \mathrm{H}$ uridine incorporation. The level of autoradiographic labelling is proposed as a criterion for assessing metabolic activity in the individual cells of the blastocyst. There was a detectable difference between the cells of the trophoblast and those of the inner cell mass (higher labelling), indicating a divergence of metabolic patterns according to blastomere differentiation. The occasional absence of nuclear labelling was correlated with cell degeneration. A low nuclear labelling was observed mainly in cells sequestered in the subzonal space or in the blastocoele cavity, respectively. Estimation of RNA synthesis in different blastomeres by fine structure autoradiography opens the way to a better interpretation of the relationship between morphology and metabolism during the development of early cow embryos.

\section{Introduction.}

Neither morphological (Shea, 1981, Lindner and Wright, 1983) nor metabolic (Hoppe and Bavister, 1984) tests have proved useful for determining the viability of early bovine embryos. The situation is similar in other monotocous species like primates where a diagnostic of the viability of morulae and blastocysts by light microscopy alone has been found to be even more difficult than in common laboratory animals (Enders et al., 1982).

As in other ungulates (Short, 1979), the mortality rate of late blastocysts in cows is high (Diskin and Sreenan, 1980). Fertilization failure in genetically normal

(1) Please address correspondence to V. Kopečný, Animal Production Research Institute, 251-61 Praha 10, Uhřínèves, Czechoslovakia. 
heifers accounts for only about $10 \%$ of overall reproductive failure, while embryonic loss accounts for more than $30 \%$. Since the major portion of this loss seems to occur between days 8 and 16 after insemination (Diskin and Sreenan, 1980), there are economic reasons for undertaking basic studies on the metabolism and ultrastructure of cleaving and differentiating cow embryos. Such a research field should give information on the causes of abnormal development and offer new perspectives for the establishment of viability tests. Liquid scintillation counting of labelled RNA extracts after ${ }^{3} \mathrm{H}$-uridine incorporation reflected marked changes in the metabolic rate of delayed rat blastocysts (review of Psychoyos, 1983 ; also see Weitlauf and Kiessling, 1980) or in the metabolic activity of mouse preimplantation embryos during indomethacin-prostaglandin $\mathrm{F}_{2 \alpha}$ treatments (Uehara et al., 1984). We have started to evaluate the transcriptional activity of porcine and bovine early embryos after ${ }^{3} \mathrm{H}$-uridine incorporation (Kopečný, Tománek, Pivko, Kaňka and Fléchon, in preparation); the autoradiographic detection of RNA synthesis enabled us to study the individual cells composing the blastocyst. The same approach in mouse embryos with abnormalities induced by parental hyperthermia already allowed the detection of a category of blastomeres which failed to incorporate ${ }^{3} \mathrm{H}$-uridine into their ribonucleic acids (Bellvé, 1976) and the author suggested that such synthetic abnormalities might be responsible for embryonic mortality. Finally, as labelling intensity after ${ }^{3} \mathrm{H}$-uridine incorporation is correlated to the rate of RNA synthesis (Maurer-Schultze, 1982), also related to protein synthesis, the use of this methodology might give an indication of the general metabolic activity of the blastomeres that constitute a young embryo.

In the present study we used electron microscope autoradiography in order to compare ultrastructure and ${ }^{3} \mathrm{H}$-uridine incorporation in individual cells of the cow blastocyst. This is of course a preliminary approach, as many factors are still to be elucidated, such as the nature of the RNA's synthesized, the efficiency of transcription, the availability of fully matured RNA's in the cytoplasm and the regulation of transcription. These goals are a challenge, as few particular cells of the embryo will be the object of such studies.

\section{Material and methods.}

Collection of bovine preimplantation embryos. - Bovine preimplantation embryos were collected between days 7 and 9 of the estrous cycle following estrus synchronization by Oestrophan (SPOFA, Czechoslovakia), a synthetic prostaglandin $F_{2 \alpha}$ analogue (Pivko et al., 1982). The cows were superovulated between days 9 and 12 of the previous estrous cycle (estrus $=$ day 0 ) by injecting them with 2,250 IU of PMSG (ANTEX, Copenhagen) or $50 \mathrm{mg}$ of FSH (Folicotropin, SPOFA, Czechoslovakia). The synchronization injection of $2 \mathrm{ml}$ of Oestrophan, i.e. $500 \mu \mathrm{g}$ of cloprostenol, was given $48 \mathrm{~h}$ later, and insemination took place after the first signs of estrus and again 8 to $10 \mathrm{~h}$ later (for further details, see Pivko et al., 1982). 
Autoradiographic study of RNA synthesis. - As for routinely successful transfer (Pivko et al., 1982), bovine early blastocysts were selected on their morphological aspect under the stereomicroscope and cultured for $30 \mathrm{~min}$ in Dulbecco's complete medium (SERVA) supplemented with $4 \mathrm{mg} / \mathrm{ml}$ of bovine serum albumin (SIGMA) and $3.7 \mathrm{MBq} / \mathrm{ml}$ of $5-{ }^{3} \mathrm{H}$-uridine (UVVVR, Prague, Czechoslovakia ; specific activity : $740 / \mathrm{GBq} / \mathrm{mM}$ ). This relatively short incubation time was chosen in order to obtain a nuclear labelling that would allow the RNA synthetic activity of individual nuclei to be compared (Maurer-Schultze, 1982) before the labelled compounds eventually migrated into the cytoplasm. After washing in precursorfree medium, the embryos were prepared for autoradiography using standard glutaraldehyde fixation and $\mathrm{OsO}_{4}$ postfixation with the addition of potassium ferricyanide. Suitable embryos showing labelling by light microscope autoradiography (ARG) were prepared for fine-structure ARG. Pale gold sections on grids, coated with Ilford L4 liquid nuclear emulsion using the loop technique, were exposed for up to three months and were then developed by D19 and contrasted with lead citrate.

\section{Results.}

The preliminary results presented here were obtained from two early blastocysts, classified as morphologically normal and showing high labelling under the light microscope. The typical electron microscope autoradiographs of the plate illustrate that, after $\mathbf{3 0}$ min incorporation, most of the cells were labelled and that the labelling remained intranuclear.

The labelling, detected in individual nuclei and expected to represent different levels of uridine- ${ }^{3} \mathrm{H}$ incorporation, showed effectively a rather wide spectrum ranging from intense nuclear labelling (figs $1,3,4,6,7$ ) to that in which grain density did not exceed background level (fig. 2). Low labelling intensity in comparison with other nuclei was observed either in segregated cells in the subzonal space (figs $3,4,5$ ) or in free cells in the blastocoele cavity. Unlabelled cells were also seen in a normal position (fig. 1). Chromatin distribution in unlabelled or poorly-labelled cells was abnormal, showing marginalization of clumps of condensed chromatin at the periphery of the cell nucleus (figs $2,3,4$ ) or alternatively less chromatin condensation (fig. 5). Segregation of the nucleolar components was also observed in the sequestered blastomeres. The main unexpected result of this study was that in most cases there was a distinct difference between the labelling intensity in the nuclei of the trophoblast cells and that of the inner cell mass, the density being higher in the latter (figs $1,6,7$ ).

\section{Discussion.}

The incorporation of ${ }^{3} \mathrm{H}$-uridine as visualized by autoradiography indicates that RNA synthesis started in the late 8-cell stage of bovine embryos (Kopechý et al., 1985). As in other species, the rate of incorporation probably increased due to an increase in the rate of RNA synthesis as well as to an enhancement of 

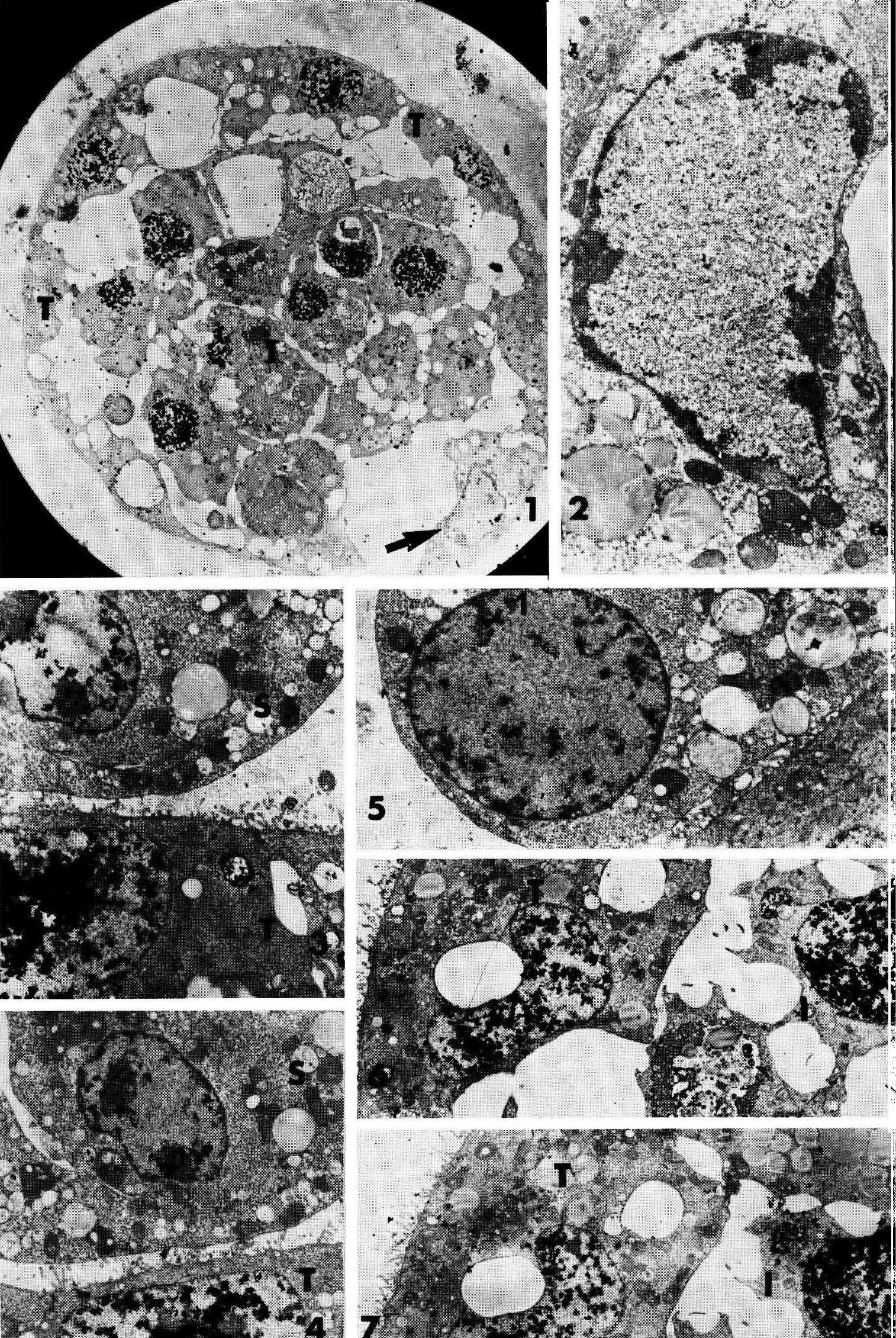

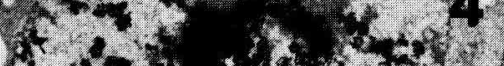

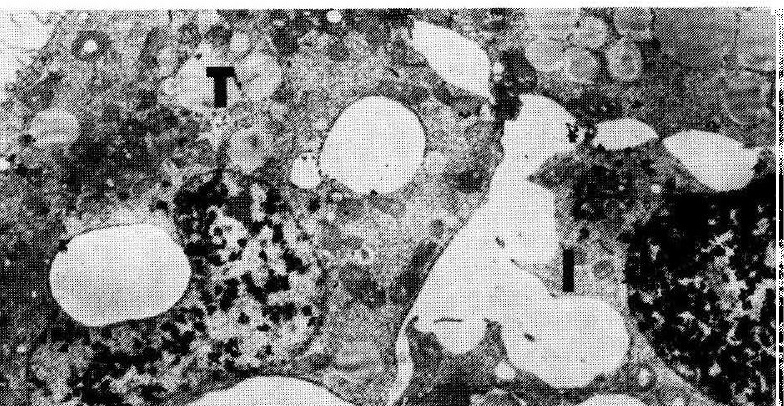


precursor uptake (see Bellvé, 1976). The rise of uridine incorporation in fresh generations of blastomeres has been demonstrated in embryos undergoing asynchronous division (Bellvé, 1976).

In the present study, there was usually a detectable difference in labelling intensity between trophoblast cell nuclei and those of the inner cell mass; this is a very early metabolic sign of the divergent differentiation of the two types of embryonic cells. Of course, we know nothing about the respective intracellular precursor pools, but note that the surrounding trophectoderm at least allowed ${ }^{3} \mathrm{H}$ uridine access to the inner cell mass. Interestingly, Van Blerkom et al. (1976) found differences in the pattern of protein synthesis between the inner cell mass and the trophectoderm in the mouse embryo.

Electron microscopic observations show that during the development of normal bovine blastocysts there are some abnormalities and cell death (Pivko, unpublished). In the fine-structural analysis of the morphology of 7-day blastocysts, previously characterized as normal under the stereo-microscope, the main ultrastructural deviations were very similar to those described by Enders et al. (1982) in the development of rhesus monkey blastocysts. These deviations included : cell fragmentation causing cellular debris to accumulate in either the interblastomeral spaces or in phagocytotic vesicles, the clustering of organelles, resulting in their absence in neighboring areas of the cytoplasm, blebbing, and lack of membrane junctions. As in primate embryos (Enders et al., 1980), the bovine blastocysts presently studied also contained a few isolated cells that were either segregated in the space between the trophoblast and the zona pellucida or free in the blastocoele cavity. These cells showed a most striking difference in

PLATE : Fine-structure autoradiographs of two bovine blastocysts (from two different donors) assessed as viable by stereo-microscopy. The blastocysts were cultured for $30 \mathrm{~min}$ with ${ }^{3} \mathrm{H}$-uridine and prepared for autoradiography.

FIG. 1. - (Embryo 497/2). With the exception of the nucleus of one trophoblast cell (arrow), all the nuclei are labelled. Note the slightly lower density of the grains overlying the nuclei of the trophoblast (T) cells compared with those of the inner cell mass (I). (X 1,100$)$.

FIG. 2. - Details of the unlabelled nucleus in figure $1(X 8,000)$. The silver grain density is not clearly above the background. The nuclear chromatin is concentrated in large peripheral blocks and the cytoplasm looks degenerated.

FIGS 3 et 4. - Low autoradiographic labelling in a cell sequestered in the subzonal space (S) (Embryo $497 / 2)$ observed on two different sections. Note the absence of junctional complexes and the " retarded " aspect of the cytoplasm and cell surface ; only a limited number of silver grains is seen around the chromatin which is more condensed at the periphery than in the trophoblast (T) celis (X $4,000)$. In both sections there is a similar difference in labelling intensity between the nucleus of the segregated cell and that of the trophoblast $(T)$ cell nucleus.

FIG. 5. - A free cell in the subzonal space. Note the consistently similar feature of lower nuclear labelling and vesiculated cytoplasm structure; some dispersed chromatin aggregates occur here $(X 5,000)$.

FIGS 6, 7. - Difference in labelling intensity between the nuclei of the trophoblast (T) and those of the inner cell mass (i). Two different sections from embryo 497/3. (X 3,500). 
nuclear ${ }^{3} \mathrm{H}$-uridine labelling, probably corresponding to retarded cell differentiation. Autoradiography also revealed a few cells that were not engaged in RNA synthesis. As expected, the cytoplasm of these cells seemed to be completely degenerated (fig. 2). In most of the abnormal cells, the segregated components of the nucleoli and the peripheral condensed chromatin of the nucleus reflected the absence of transcription (Simard, 1970). On the whole the blastocysts nevertheless appeared normal at the ultrastructural level, including, as habitually, a few degenerating or discarded cells. The observations of the present study will be reinforced by a more detailed study showing a broader spectrum of deviation in ${ }^{3} \mathrm{H}$-uridine incorporation in a variety of abnormal or experimentally damaged cells in the early preimplantation embryos of cows and pigs (Kopecny et al., in preparation). We are aware that such an extension of our studies still constitutes an a posteriori test, but it can at least show the effects of in vitro manipulation of blastocysts and signal the impairment of fundamental cell functions which would otherwise escape attention.

In conclusion, we have probably detected early differences in RNA synthesis between the first two embryonic tissues of the cow blastocyst as well as a lower rate of synthesis in cells degenerating in situ or in discarded blastomeres. These results fit well with the concept that differentiation of the mammalian embryo is dependent upon early transcription (Bolton, Oades and Johnson, 1984), although there may be small species differences in timing (Kopečný et al., 1985 ; Tesarik et al., 1986).

Colloque franco-tchécoslovaque,

I.N.R.A., Jouy-en-Josas, 5-6 décembre 1984.

Acknowledgments. - We thank Dr Cran for his critical reading of the manuscript, $\mathrm{C}$. Slagmulder for printing the plate and Mrs A. Daifuku for editing the text.

Résumé. Autoradiographie de l'incorporation d'uridine ${ }^{3}{ }^{3} H$ dans le jeune blastocyste bovin normal.

La synthèse d'ARN dans de jeunes blastocystes bovins morphologiquement normaux, récoltés sept jours après insémination, est étudiée par autoradiographie en microscopie électronique après incorporation d'uridine ${ }^{3}-\mathrm{H}$. L'intensité du marquage autoradiographique est proposée comme un critère de l'activité métabolique des différents blastomères. Les cellules de la masse cellulaire interne apparaissent sensiblement plus marquées que celles du trophoblaste; ceci représente probablement une différence d'activité de synthèse entre des lignées cellulaires dont la différentiation diverge. L'absence, occasionnelle, de marquage nucléaire est observée dans des cellules en dégénérescence. Un faible marquage est typique des cellules séquestrées dans le blastocoele ou sous la zone pellucide. L'évaluation de l'activité individuelle de synthèse d'ARN des blastomères par l'autoradioradiographie en microscope électronique constitue une première étape dans l'étude des corrélations entre la morphologie et le métabolisme pendant le développement précoce de l'embryon bovin. 


\section{References}

BELLVÉ A. R., 1976. Incorporation of $\left({ }^{3} \mathrm{H}\right)$ uridine by mouse embryos with abnormalities induced by paternal hyperthermia. Biol. Reprod., 15, 632-646.

BOLTON V. N., OADES P. J., JOHNSON M. H., 1984. The relationship between cleavage, DNA replication and gene expression in the mouse 2-cell embryo. J. Embryol. exp. Morph., 79, 139-163.

DISKIN M. G., SREEMAN J. M., 1980. Fertilization and embryonic mortality rates in beef heifers after artificial insemination. J. Reprod. Fert., 59, 463-468.

ENDERS A. C., HENDRICKX A. G., BINKERD P. E., 1982. Abnormal development of blastocysts and blastomeres in the Rhesus monkey. Biol. Reprod., 26, 353-366.

HOPPE R. W., BAVISTER B. W., 1984. Evaluation of fluorescein diacetate (FDA) vital dye viability test with hamster and bovine embryos. Anim. Reprod. Sci., 6, 323-335.

KOPEČNÝ V., FLĖCHON J.-E., TOMÁNEK M., CAMOUS S., KAŇKA J., 1985. Ultrastructural analysis of ${ }^{3} \mathrm{H}$-uridine incorporation in early embryos of pig and cow (Abstr.). ECBO 9th Nucleolar Workshop, Cracow, p. 31.

KOPEČNY̆ V., TOMANEK M., PIVKO J., KAÑKA J., FLÉCHON J.-E., 1985. RNA synthesis as a parameter of early mammalian embryo viability (in preparation).

LINDNER G. M., WRIGHT R. W., 1983. Bovine embryo morphology and evaluation. Theriogenology, 20, 407-416.

MAURER-SCHULTZE B., 1982. Various autoradiographic methods as a tool in cell-growth studies, 83-111. In C. NICOLIN, Cell Growth, Plenum Publ. Corp.

PIVKO J., MOTLIK J., PAVLOK A., TOMÁNEK M., MAJERČIAK P., GRAFENAU P., VANČINŠIN J., 1982. The embryo transfer in cattle during controlled production of twins (in Slovak). Vet. Med. (Prague), 27. 395-404.

PSYCHOYOS A., 1973. Endocrine control of egg implantation, 187-215. In GREEP R. O., Handbook of physiology. Endocrinology, section 7, Endocrinology, vol. II, Part 2, Am. physiol. Soc., Washington.

SHEA B. F., 1981. Evaluating the bovine embryo. Theriogenology, 15, 31-42.

SHORT R. V., 1979. When a conception becomes a pregnancy. In Maternal recognition of pregnancy, Ciba Found. Symp., 64, 377-387.

SIMARD R., 1970. The nucleus : Action of chemical and physical agents. Int. Rev. Cytol., 28, 169211.

TESAŘIK J., KOPEĆNÝ V., PLACHOT M., MANDELBAUM J., DA LAGE C., FLÉCHON J.-E., 1986. Nucleologenesis in the human embryo developing in vitro. Ultrastructural and autoradiographic analysis. Dev. Biol. (in press).

VAN BLERKOM J., BARTON S. C., JOHNSON M. H., 1976. Molecular differentiation in the preimplantation mouse embryo. Nature, 259, 319-321.

WEITLAUF H. M., KIESSLING A., 1980 . Comparison of overall rates of RNA synthesis in implanting and delayed implanting mouse blastocyst in vitro. Dev. Biol., 77, 116-129.

UEHARA S., VILLEE C. A., HOSHIAI H., 1984. Effect of indomethacin and prostaglandin $F_{2 \alpha}$ on incorporation of $\left({ }^{3} \mathrm{H}\right)$ uridine by preimplantation mouse embryo. Tohoku J. exp. Med., 143. 219-226. 